\title{
Growth Curve of Selectively Bred Tambaqui (Colossoma macropomum) Reared in Different Environments
}

\author{
Rebeca Marcos (Corresponding Author) \\ Federal University of Mato Grosso do Sul (UFMS), Faculty of Veterinary Medicine and \\ Animal Science, Campo Grande, Mato Grosso do Sul, Brazil \\ E-mail: rebecaxodo@hotmail.com
}

\section{Ruy Alberto Caetano Corrêa Filho}

Federal University of Mato Grosso do Sul (UFMS), Faculty of Veterinary Medicine and Animal Science, Campo Grande, Mato Grosso do Sul, Brazil

\section{Janessa Sampaio de Abreu}

Federal University of Mato Grosso (UFMT), Faculty of Agronomy and Zootechnics, Cuiabá, Mato Grosso, Brazil

Guilherme do Nascimento Seraphim

Federal University of Mato Grosso do Sul (UFMS), Faculty of Veterinary Medicine and Animal Science, Campo Grande, Mato Grosso do Sul, Brazil

Ana Carla Carvalho Silva

Federal University of Mato Grosso do Sul (UFMS), Faculty of Veterinary Medicine and Animal Science, Campo Grande, Mato Grosso do Sul, Brazil

\section{Darci Carlos Fornari}

Auburn University, School of Fisheries, Aquaculture and Aquatic Sciences, Auburn, Alabama, USA 
Ricardo Pereira Ribeiro

State University of Maringa (UEM), Department of Zootechnics, Paraná, PR, Brazil

\title{
Luana Barbosa Pires
}

Federal University of Mato Grosso do Sul (UFMS), Faculty of Veterinary Medicine and Animal Science, Campo Grande, Mato Grosso do Sul, Brazil

\section{Thiago Xavier Martins}

Federal University of Mato Grosso do Sul (UFMS), Faculty of Veterinary Medicine and Animal Science, Campo Grande, Mato Grosso do Sul, Brazil

\section{Jayme Aparecido Povh}

Federal University of Mato Grosso do Sul (UFMS), Faculty of Veterinary Medicine and Animal Science, Campo Grande, Mato Grosso do Sul, Brazil

Received: Feb. 3, 2020

doi:10.5296/jas.v8i3.16379
Accepted: Apr. 14, 2020 Published: Apr. 29, 2020

URL: https://doi.org/10.5296/jas.v8i3.16379

\begin{abstract}
The objective of this study was to obtain the growth curve of selectively bred tambaqui (Colossoma macropomum) reared in different environments. The experiment was carried out in the municipalities of Santo Antônio de Leverger (Mato Grosso - MT) and Campo Grande (Mato Grosso do Sul - MS), Brazil, over 431 days. Weight and morphometric traits of two families (A and B) from the second generation of selective breeding (G2) were measured every 30-45 days. The Gompertz regression model was used to obtain the growth curves. The production performance of both families and the interaction between families and locations (genotype $\times$ environment) were evaluated by analysis of variance considering the family (A and $\mathrm{B}$ ), location (MT and MS), family $\times$ location interaction and error as variation factors. The asymptotic value (parameter A) obtained for weight and morphometric traits (except head length) was higher $(\mathrm{P}<0.05)$ in MT (weight of families A and B: $2279.6 \mathrm{~g}$ ) than in MS (weight of family A: $1400.0 \mathrm{~g}$; weight of family B: $1600.0 \mathrm{~g}$ ). Family B showed better production performance in MS. There was a genotype $\times$ environment interaction effect on weight, body length and standard length. The two families have distinct growth patterns in different production environments. Family B has better growth performance in the environment with lower temperatures (MS).
\end{abstract}


Keywords: asymptotic value, genetic selection, Gompertz, fish breeding, production performance

\section{Introduction}

Tambaqui, Colossoma macropomum (Cuvier, 1818), a member of the order Characiformes, family Characidae and sub-family Myleinae, is a fish species native to the Amazon basin and widespread in tropical parts of South America and Central Amazon (Araújo-Lima and Goulding, 1998). The species is of great importance for the fishing and aquaculture activities developed in many South American countries (Lopera-Barrero et al., 2011).

The lack of native fish breeding programs in Brazil has led many fish farmers to produce hybrid fish in an effort to increase their production. Notable examples of such hybrids are tambacu (female tambaqui $*$ male pacu) and tambatinga (female tambaqui $\times$ male pirapitinga) (Lopera-Barrero et al., 2011). Although tambaqui was the most widely farmed native fish in Brazil in $2018(102,554 \mathrm{t}=14.6 \%$ of the total fish production), hybrids also occupy a second prominent position in this rank $(54,276 \mathrm{t}=7.7 \%$ of the total fish production) (IBGE, 2020).

However, although hybrid fish may have a higher yield potential than their parents, this gain is restricted to a single generation, where as the genetic gain achieved with selective breeding continues throughout subsequent generations (Ponzoni et al., 2005). Although positive heterosis can be present in some conditions, when there is genetic gain, if ever, it is restricted to one generation. Through selective breeding, however, gains of 8-12\% can be obtained per generation in well-managed programs (Nguyen, 2016), possibly reaching up to 15\% (Ponzoni et al., 2005).

In Brazil, fish breeding programs are rather recent. The first native-fish breeding program in the country started only in 2008, with the tambaqui species (Oliveira et al., 2012). The first generation (G1) of selective breeding for weight gain was formed in the 2011/2012 reproductive period, and the fish from the evaluated G1 families were approximately $17.6 \%$ superior in performance to those which had not been selectively bred for weight gain (Marcos et al., 2016). The recent production of the second generation (G2) of selection for weight gain has reinforced the importance of evaluating the growth curves of families from that generation in different environments. Determining the growth curves based on the curve parameters (A: asymptotic value; B: relative growth rate; $\mathrm{C}$ : age at the inflection point) can help the breeding program in obtaining earlier-developing fish and/or fish with a higher growth rate at a given age. In this respect, the Gompertz model has been used to describe the growth of fish such as Nile tilapia (Oreochromis niloticus) (Oliveira et al., 2012) and tambaqui (De Mello et al., 2015).

In view of the above scenario, the present study was undertaken to obtain the growth curve of selectively bred tambaqui reared in different environments.

\section{Materials and Methods}

\subsection{Experimental Sites and Animals}

The experiment was carried out from November 2015 to February 2017at the Farming Station of the Experimental Farm of the Federal University of Mato Grosso (UFMT), located in the 
municipality of Antônio de Leverger, MT, Brazil (15 $51^{\prime} 56^{\prime \prime} \mathrm{S}$ and $\left.56^{\circ} 04^{\prime} 36^{\prime \prime} \mathrm{W}\right)$; and at the Experimental Fish Farming Station of the Federal University of Mato Grosso do Sul (UFMS), located in the municipality of Campo Grande, MS, Brazil (20²9'59''S and 54'36'53'W). All animal procedures were approved by the Ethics Committee on Animal Use of the Federal University of Mato Grosso do Sul (CEUA/UFMS/641/2014).

The second generation of selective breeding for weight gain in tambaqui was obtained in the reproductive season of 2015 (April), at the breeding center located in northern Mato Grosso State $\left(-12^{\circ} 51^{\prime} 56,40^{\prime} \mathrm{S}\right.$ and $\left.-55^{\circ} 50^{\prime} 03,30^{\prime} \mathrm{W}\right)$. The fingerlings were obtained from the cross between mothers from the first generation of selective breeding for weight gain, which originated the two families (A and B) that were evaluated in the present experiment. Initially, the fingerlings were stocked in two $3.0-\mathrm{m}^{3}$ net cages separated per family that were lateral located to tanks in the Fish Farming Station of the Experimental Farm of the Federal University of Mato Grosso. The fish remained in the net cages until reaching the predetermined size to be individualized with a microchip implanted in the back region.

\subsection{Experimental Units, Feeding and Water Analysis}

The tambaqui families were distributed into two environments for the experiment, namely, Santo Antônio de Leverger (MT) and Campo Grande (MS). A total of 1200 fish with an initial live weight of $130.2 \pm 1.9 \mathrm{~g}$ and a total length of $21.0 \pm 1.8 \mathrm{~cm}$ were allocated at random to the two farming sites, using 600 fish per production environment (MT and MS). Each tank (two per location) housed 300 fish (150 of each family).

The fish were produced in a semi-intensive system with $10 \%$ daily water renewal. A final biomass of $0.8 \mathrm{~kg}$ fish $\mathrm{m}^{-2}$ was estimated in both production environments. The fish received an extruded feed (32\% crude protein, $6.5 \%$ ether extract, $4 \%$ crude protein, $14 \%$ mineral matter and $88 \%$ dry matter) twice daily (0900 and $1600 \mathrm{~h})$, with the pellet size adjusted according to the production phase. The fish were fed to apparent satiety.

Water limnological characteristics were evaluated weekly over the course of the experimental period. In the tanks of Santo Antônio de Leverger (MT), temperature and dissolved oxygen were measured with a digital oxymeter (Yellow Springs Instruments - YSI Pro 20) and the pH was measured with a digital $\mathrm{pH}$ meter (Quimis ${ }^{\circledR} \mathrm{Q} 400 \mathrm{BC}$ ). The same analyses were performed in the tanks of Campo Grande (MS) using a multi-parameter instrument (YSI Professional Plus).

\subsection{Evaluated Traits}

The second selectively bred generation of tambaqui was evaluated over a period of 431 days (November 2015 to February 2017) in the two locations (MT and MS). Biometric measurements were taken every 30-45 days. Prior to these, the fish were feed-deprived for 24 $\mathrm{h}$ and then anesthetized with eugenol solution $\left(50 \mathrm{mg} \mathrm{L}^{-1}\right)$ as proposed by Inoue et al. (2011). Next, the fish were identified (microchip reading) and weighed, and the following morphometric variables were then measured: standard length, head length, and body circumference (Figure 1). 


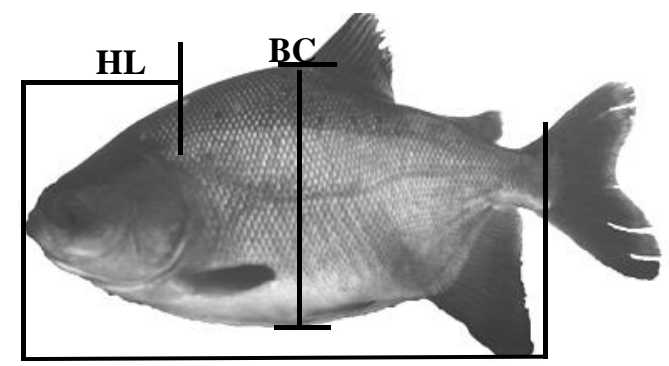

SL

Figure 1. Morphometric measurements of tambaqui (Colossoma macropomum): HL (head length), BC (body circumference), and SL (standard length)

\subsection{Statistical Analysis}

The non-linear mathematical regression model of Gompertz (Fialho, 1999) described below was used to describe the growth behavior of the tambaqui family:

$$
y_{i}=A \cdot e^{-e^{-B \cdot(t-i)}}
$$

Where

$Y_{i}=$ weight $(\mathrm{g})$ or size $(\mathrm{cm})$ estimated at age $t$;

$A=$ asymptotic weight $(\mathrm{g})$ or size $(\mathrm{cm})$ when $t$ tends to plus infinite; i.e., this parameter can be interpreted as the weight or size when the fish cease to grow;

$B=$ relative growth at the inflection point ( $\mathrm{g} /$ day for $\mathrm{g}$ of fish or $\mathrm{cm} /$ day for $\mathrm{cm}$ of fish);

$C=$ age at the inflection point (days);

$t=$ age (days); and

$e=2.718281828459$.

The models were fitted to describe the growth pattern of the fish in the two families selected for weight and all morphometric traits measured. The parameters of the growth curve of the fish from both families were estimated by a modified version of the Marquardt method, using the NLIN procedure of $\mathrm{SAS}^{\circledR}$ software version 9.0.

Eight different models were used to compare the growth models of the families in each location. The simplest model $\left(\mathrm{M}_{8}\right)$ considers that the parameters of Gompertz functions are unique for both families, where as the full model $\left(\mathrm{M}_{1}\right)$ considers that each family has a specific parameter. The other models evaluated in the comparison of the growth curves consider different restrictions, with one or two parameters in common, as shown in Table 1. 
Table 1. Parameters of different models used in the comparison of the growth curves of two families (A and B) of tambaqui (Colossoma macropomum) from the second generation of selective breeding for weight gain in Santo Antônio de Leverger (MT) and Campo Grande (MS)

\begin{tabular}{|c|c|c|c|c|c|c|c|c|}
\hline \multicolumn{9}{|c|}{ Model } \\
\hline & $\mathbf{M}_{1}$ & $\mathbf{M}_{2}$ & $\mathbf{M}_{3}$ & $\mathbf{M}_{4}$ & $\mathbf{M}_{5}$ & $\mathbf{M}_{6}$ & $\mathbf{M}_{7}$ & $\mathbf{M}_{8}$ \\
\hline \multirow{3}{*}{ 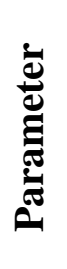 } & $A i$ & $A$ & $A i$ & $A i$ & $A$ & $A$ & $A i$ & $A$ \\
\hline & $B i$ & $B i$ & $B$ & $B i$ & $B$ & $B i$ & $B$ & $B$ \\
\hline & $C i$ & $C i$ & $C i$ & $C$ & $C i$ & $C$ & $C$ & $C$ \\
\hline
\end{tabular}

$A, B$ and $C$ parameters belonging to the Gompertz model.

$i=$ index for the identification of family (A and B).

To compare the growth curve of the two families in each location and assess model adequacy, the likelihood ratio test was used for equality of non-linear model parameters, with chi-square $\left(\chi^{2}\right)$ approximation, as proposed by Regazzi and Silva (2004).

To compare the performance of the families (A and B) and identify the interaction between families and locations, an analysis was undertaken using information from the biometric measurements when the fish from both locations had approximate average weights of 1300.0 g: in MT, at the sixth biometric measurement event (392 and 393 days) and in MS, at the ninth event (701 days).In the analysis of variance, the family effect (A and B), location effect (MT and MS), family $\times$ location interaction effect and error were adopted as sources of variation. For comparisons between the families and between the two locations, Tukey's test was applied at the $5 \%$ significance level.

\section{Results}

In the tanks of Santo Antônio de Leverger (MT), water temperature at the beginning of the experiment (November) was $24.7 \pm 2.4{ }^{\circ} \mathrm{C}$, which rose continuously until March $(31.0 \pm$ $\left.0.4{ }^{\circ} \mathrm{C}\right)$, dropped in the winter $\left(24.6 \pm 2.4{ }^{\circ} \mathrm{C}\right)$ and increased again at the end of the trial $(28.5$ $\left.\pm 0.7^{\circ} \mathrm{C}\right)$. Dissolved oxygen was found at a moderate concentration $\left(2.7 \pm 0.3 \mathrm{mgL}^{-1}\right)$ at the onset of the experiment, showing peaks of variation throughout it (from $1.2 \pm 1.1 \mathrm{mg} \mathrm{L}^{-1}$ in February to $7.2 \pm 2.2 \mathrm{mg} \mathrm{L}^{-1}$ in July) and reaching a moderate concentration $\left(2.2 \pm 0.3 \mathrm{mg} \mathrm{L}^{-1}\right)$ at the end of the experiment. The $\mathrm{pH}$ value was medium at the start of the experiment $(8.1 \pm$ 1.0), fluctuated moderately throughout it (from $6.2 \pm 2.0$ in December to $8.9 \pm 0.7$ in July) and reached its lowest value $(6.4 \pm 1.2)$ at the end (Figure 2$)$.

In the tanks of Campo Grande (MS), water temperature at the onset of the experiment (December) was $26.3 \pm 0.6{ }^{\circ} \mathrm{C}$, which remained stable until March $\left(26.0 \pm 0.7{ }^{\circ} \mathrm{C}\right)$, declined 
sharply in the winter $\left(19.8 \pm 1.7^{\circ} \mathrm{C}\right)$ and increased again at the end of the experiment $(27.0 \pm$ $0.6^{\circ} \mathrm{C}$ ), always at a lower magnitude than that observed in MT. Dissolved oxygen was higher at the beginning $\left(3.4 \pm 0.6 \mathrm{mg} \mathrm{L}^{-1}\right)$ than at the end of the experiment $\left(1.5 \pm 0.7 \mathrm{mg} \mathrm{L}^{-1}\right)$, varying greatly throughout it (from $1.5 \pm 0.6 \mathrm{mg} \mathrm{L}^{-1}$ in February to $8.7 \pm 0.1 \mathrm{mg} \mathrm{L}^{-1}$ in September). The $\mathrm{pH}$ varied little throughout the trial, starting at $8.3 \pm 0.1$ and ending at $7.9 \pm$ 0.2 (Figure 2).
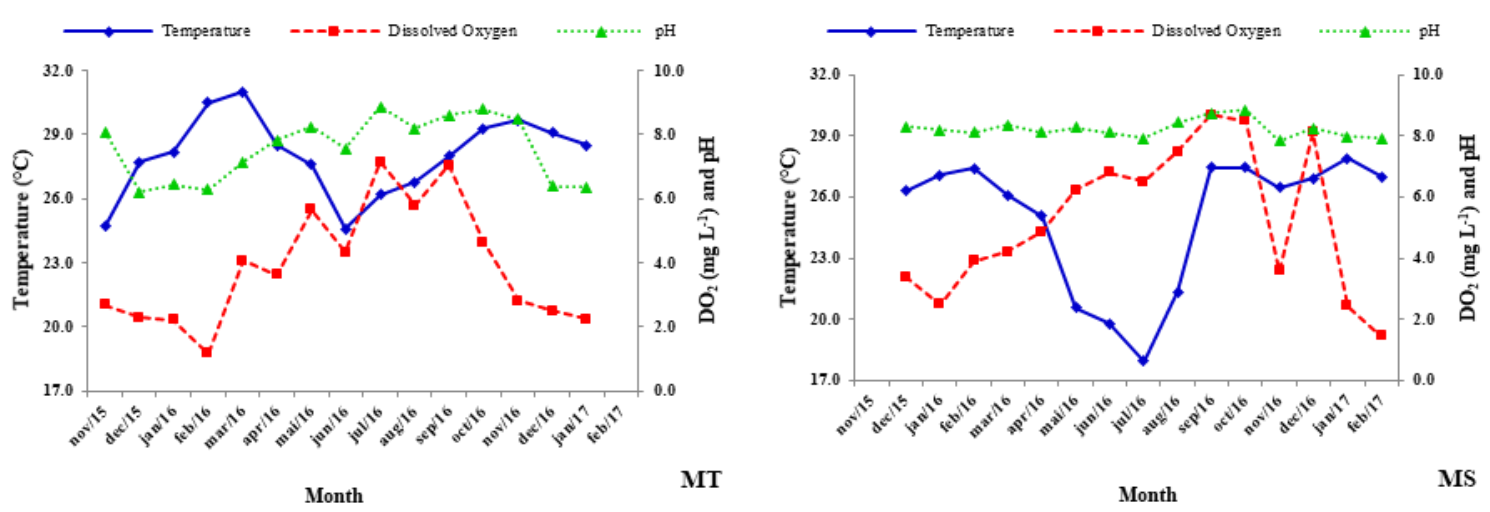

Figure 2. Mean temperature $\left({ }^{\circ} \mathrm{C}\right)$, dissolved oxygen $\left(\mathrm{DO}_{2}\right)$ and $\mathrm{pH}$ values in the water of tanks used for farming tambaqui (Colossoma macropomum) from the second generation of selective breeding in Santo Antônio de Leverger (MT) and Campo Grande (MS)

The analysis of the growth of the families (A and B) in different environments using model $\mathrm{M}_{1}$ (most complete model) revealed a higher asymptotic value (parameter $\mathrm{A}$ ), a higher relative growth rate (parameter B) and a lower age at the inflection point (parameter C) for the families farmed in MT than in those reared in MS. The exception was the asymptotic value for head length, which was higher in MS for both families. Age at the inflection point for standard length (A and B), head length (B) and body circumference (B) was lower in MT. The same trend was observed with the use of the best-fitting model for all evaluated traits (Table 2).

The most suitable model to describe head length in both locations was $\mathrm{M}_{1}$, where as $\mathrm{M}_{5}$ was the most adequate for the other traits in MT. In the MS location, $\mathrm{M}_{3}$ (weight and body circumference) and $\mathrm{M}_{5}$ (standard length) were the most suitable model for the other traits (Table 2). Final biomass was similar in both locations: 0.59 and $0.62 \mathrm{~kg}$ fish $\mathrm{m}^{-2}$ in MT and MS, respectively. However, the asymptotic weight obtained by the best-fitting model was considerably higher in MT than in MS, for both families (Table 2). 
Table 2. Parameter estimates of the full model $\left(\mathrm{M}_{1}\right)$ and of the best-fitting models to describe the growth pattern of two families (A and B) of tambaqui (Colossoma macropomum) from the second generation of selective breeding evaluated in Santo Antônio de Leverger (MT) and Campo Grande (MS)

\begin{tabular}{|c|c|c|c|c|c|c|c|c|c|}
\hline & & \multicolumn{4}{|c|}{ Santo Antônio de Leverger (MT) } & \multicolumn{4}{|c|}{ Campo Grande (MS) } \\
\hline & & \multicolumn{8}{|c|}{ Trait } \\
\hline & & Weight & SL & HL & BC & Weight & SL & HL & BC \\
\hline & Parameter & & & & Fam & $\mathbf{y} \mathbf{A}$ & & & \\
\hline \multirow{8}{*}{ 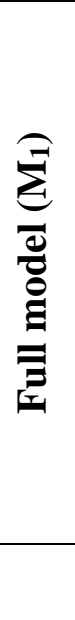 } & $A$ & 2251.7 & 39.8 & 11.1 & 39.9 & 1400.0 & 36.1 & 11.8 & 36.6 \\
\hline & $B$ & 0.0110 & 0.0097 & 0.0123 & 0.0118 & 0.0060 & 0.0043 & 0.0047 & 0.0045 \\
\hline & $C$ & 338.7 & 225.7 & 214.5 & 232.8 & 437.1 & 239.6 & 236.4 & 224.2 \\
\hline & & \multicolumn{8}{|c|}{ Family B } \\
\hline & $A$ & 2301.2 & 39.9 & 12.6 & 40.2 & 1600.0 & 37.7 & 13.0 & 38.7 \\
\hline & $B$ & 0.0106 & 0.0095 & 0.0069 & 0.0113 & 0.0070 & 0.0039 & 0.0039 & 0.0040 \\
\hline & \multirow[t]{2}{*}{$C$} & 333.8 & 215.7 & 193.4 & 222.9 & 386.6 & 171.8 & 182.2 & 165.6 \\
\hline & & \multicolumn{8}{|c|}{ Family A } \\
\hline \multirow{8}{*}{ 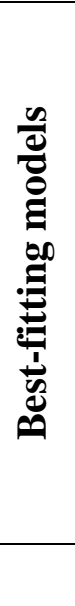 } & $A$ & 2279.6 & 39.8 & $11.1^{*}$ & 40.0 & $1400.0^{*}$ & 36.9 & $11.8^{*}$ & $37.2 *$ \\
\hline & $B$ & 0.0108 & 0.0096 & $0.0123^{*}$ & 0.0115 & 0.0065 & 0.0041 & $0.0047 *$ & 0.0043 \\
\hline & $C$ & $340.5^{*}$ & $225.5^{*}$ & $214.5^{*}$ & $232.5^{*}$ & $428.4^{*}$ & $244.8^{*}$ & $236.4^{*}$ & $225.4^{*}$ \\
\hline & & \multicolumn{8}{|c|}{ Family B } \\
\hline & $A$ & 2279.6 & 39.8 & $12.6^{*}$ & 40.0 & $1600.0^{*}$ & 36.9 & $13.0^{*}$ & $38.0 *$ \\
\hline & $B$ & 0.0108 & 0.0096 & $0.0069 *$ & 0.0115 & 0.0065 & 0.0041 & $0.0039 *$ & 0.0043 \\
\hline & $C$ & $332.4 *$ & $215.9 *$ & $193.4^{*}$ & $223.3^{*}$ & $391.0 *$ & $169.8^{*}$ & $182.2 *$ & $167.0 *$ \\
\hline & Model & $\mathbf{M}_{5}$ & $\mathbf{M}_{5}$ & $\mathbf{M}_{1}$ & $\mathbf{M}_{5}$ & $\mathbf{M}_{3}$ & $\mathbf{M}_{5}$ & $\mathbf{M}_{1}$ & $\mathbf{M}_{3}$ \\
\hline
\end{tabular}

$A$ (g or $\mathrm{cm}), B$ (g/day for $\mathrm{g}$ of fish or $\mathrm{cm} /$ day for $\mathrm{cm}$ of fish) and $C$ (days) parameters belonging to the Gompertz model.

Model $=$ Best-fitting model according to $\chi^{2}$ statistic $(\mathrm{P}<0.05)$.

SL: standard length; HL: head length; BC: body circumference.

*Parameters followed by an asterisk differ between families for the same trait and location. 


\section{Macrothink}

The estimate of weight parameters obtained in the fish from MT only differed significantly for age at the inflection point (parameter $\mathrm{C}$ ), which was higher $(\mathrm{P}<0.05)$ in family $\mathrm{B}$ (model $\mathrm{M} 5)$. In MS, age at the inflection point was also higher $(\mathrm{P}<0.05)$ in family $\mathrm{B}$, but the asymptotic weight also differed significantly, with a higher $(\mathrm{P}<0.05)$ value found in family $\mathrm{B}$ (model M3) (Table 2; Figure 3).
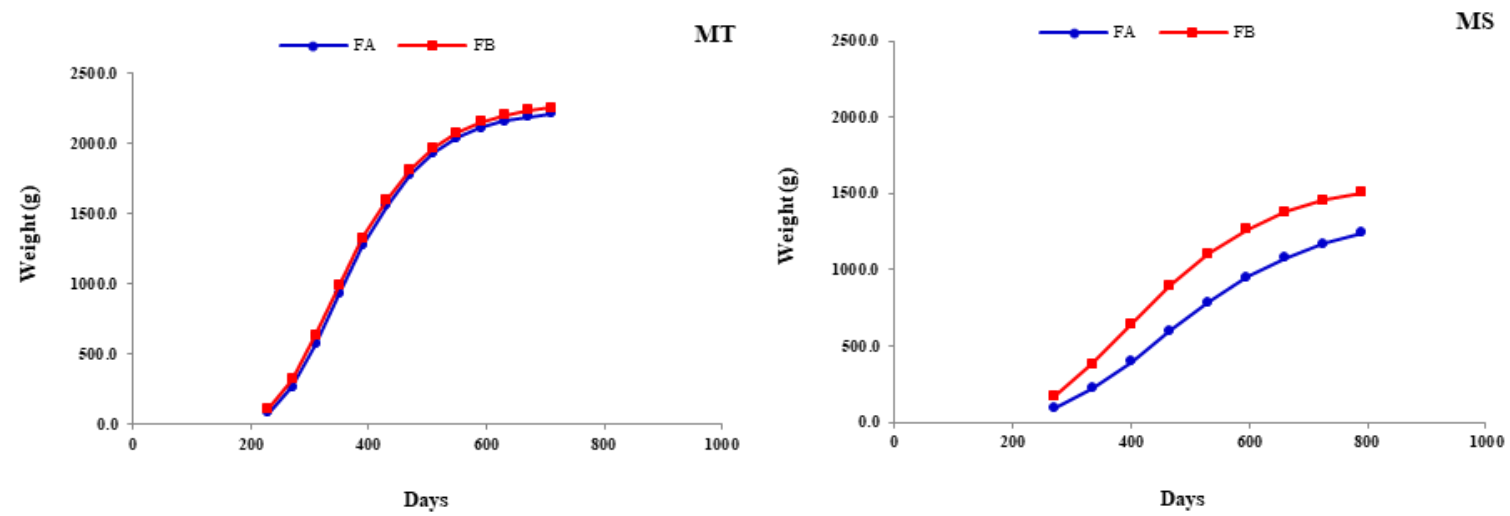

Figure 3. Growth curves of weight (g) as a function of age (days) in two families (A and B) of tambaqui (Colossoma macropomum) from the second generation of selective breeding evaluated in Santo Antônio de Leverger (MT) and Campo Grande (MS)

The only significantly different parameter for standard length was age at the inflection point, which was higher $(\mathrm{P}<0.05)$ in family $\mathrm{A}$ in both locations (model $\mathrm{M} 5)$ (Table 2; Figure 4).
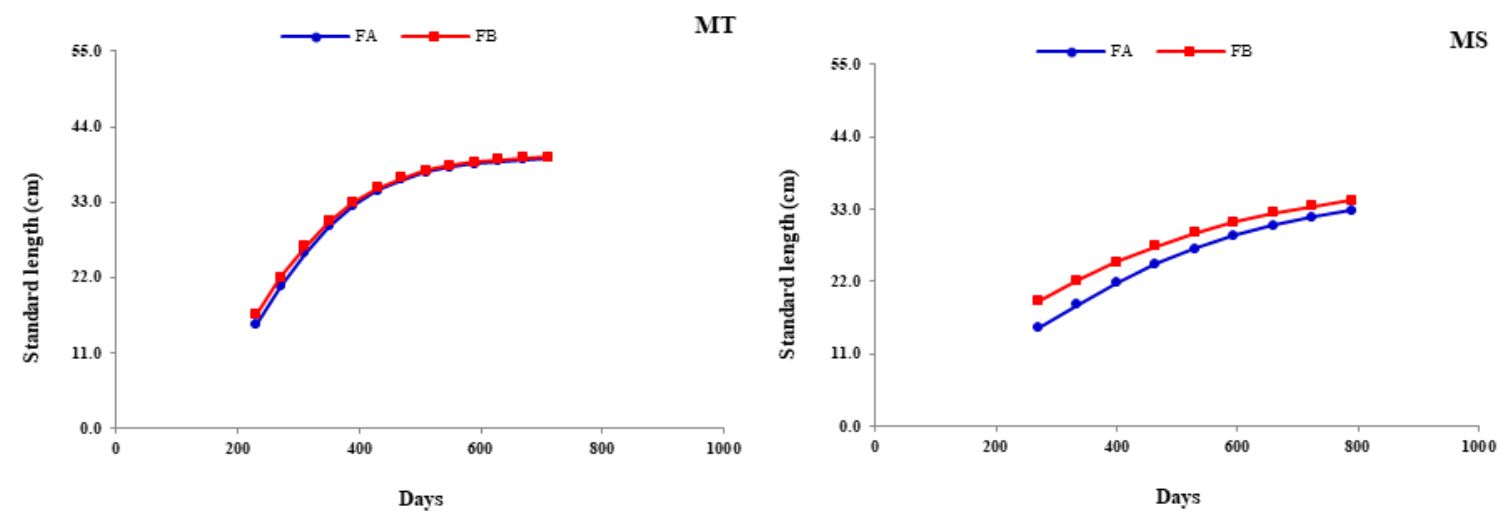

Figure 4. Growth curves of standard length (cm) as a function of age (days) in two families (A and B) of tambaqui (Colossoma macropomum) from the second generation of selective breeding evaluated in Santo Antônio de Leverger (MT) and Campo Grande (MS)

All growth curve parameters in model $\mathrm{M}_{1}$ were significantly different for head length in both locations. The asymptotic value was higher $(\mathrm{P}<0.05)$ in family $\mathrm{B}$ than in family A. Relative growth rate and age at the inflection point were also higher $(\mathrm{P}<0.05)$ for family $\mathrm{A}$ in both locations (Table 2; Figure 5). 

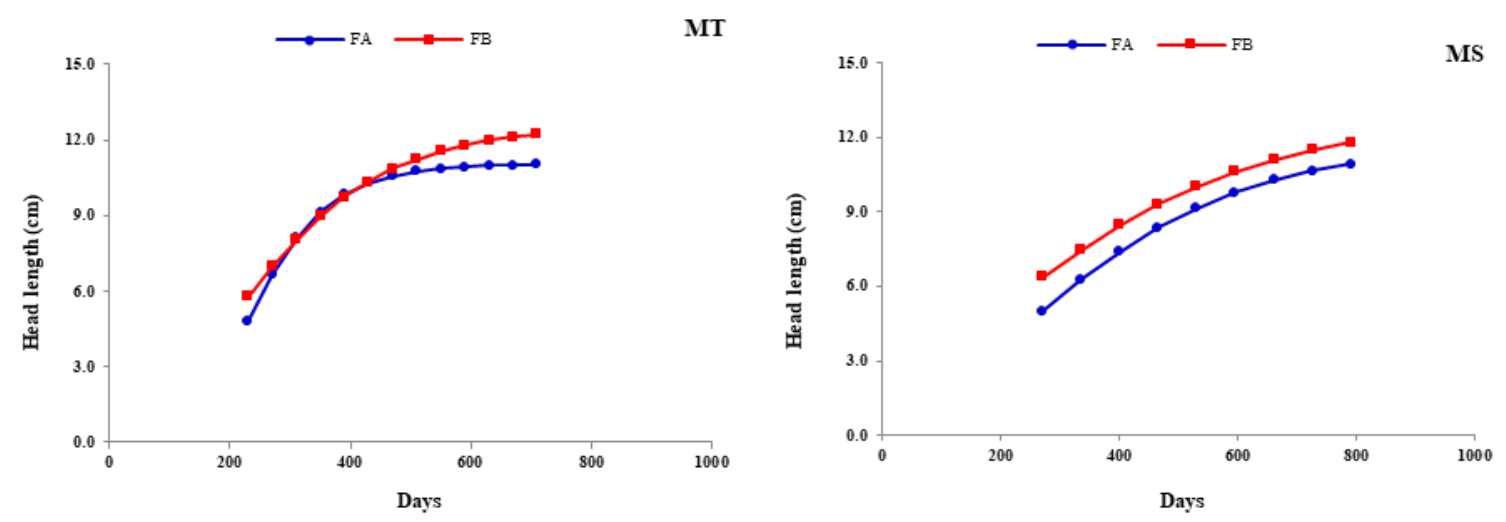

Figure 5. Growth curves of head length (cm) as a function of age (days) in two families (A and B) of tambaqui (Colossoma macropomum) from the second generation of selective breeding evaluated in Santo Antônio de Leverger (MT) and Campo Grande (MS)

In the fish from MT, body length was only significantly different for age at the inflection point, with a higher $(\mathrm{P}<0.05)$ value seen in family A (model M5). In MS, the higher $(\mathrm{P}<0.05)$ value for this parameter was also obtained by family A, but the asymptotic value was also significantly different, with a higher $(\mathrm{P}<0.05)$ value observed in family $\mathrm{B}\left(\operatorname{model} \mathrm{M}_{3}\right)($ Table 2; Figure 6).
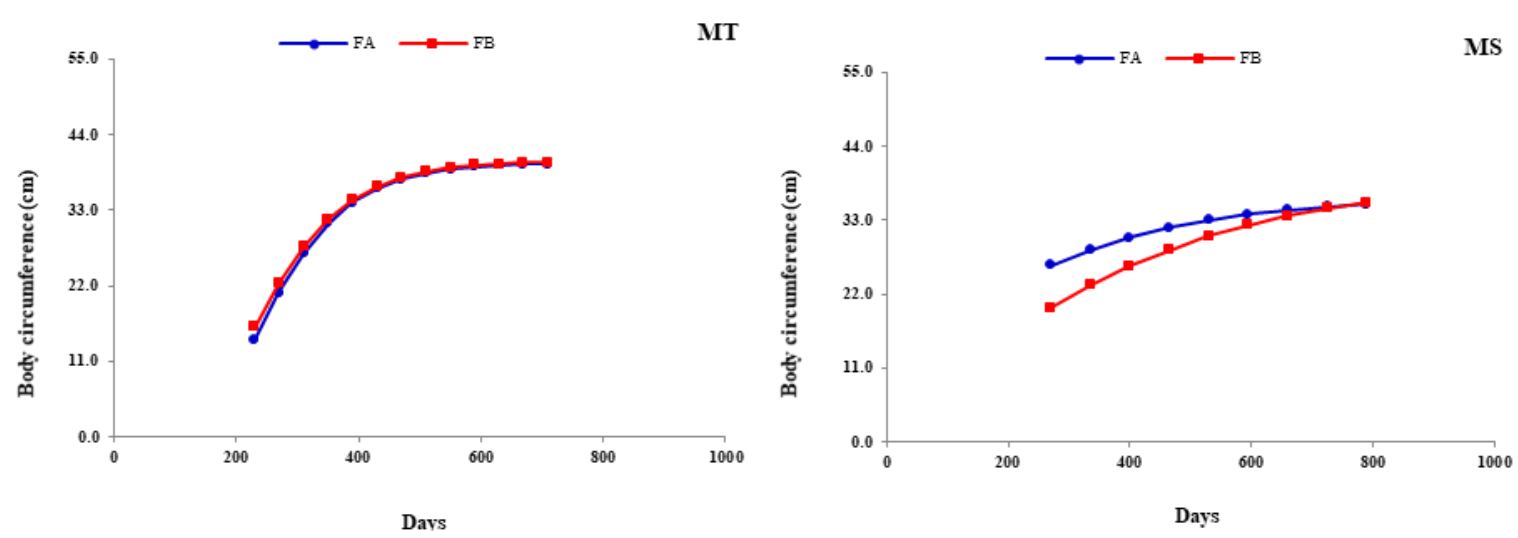

Figure 6. Growth curves of body circumference $(\mathrm{cm})$ as a function of age (days) in two families (A and B) of tambaqui (Colossoma macropomum) from the second generation of selective breeding evaluated in Santo Antônio de Leverger (MT) and Campo Grande (MS)

In MT, weight and standard length were higher $(\mathrm{P}<0.05)$ in family $\mathrm{B}$. This family also showed higher $(\mathrm{P}<0.05)$ values for these traits and for body circumference in MS. For family $\mathrm{A}$, weight and body circumference were higher $(\mathrm{P}<0.05)$ when the fish were grown in MT than in MS, whereas for family $\mathrm{B}$, standard length was higher $(\mathrm{P}<0.05)$ in MS than in MT. These traits were all influenced $(\mathrm{P}<0.05)$ by the genotype $\times$ environment interaction, except head length. When evaluated independently of location and family, the highest $(\mathrm{P}<0.05)$ head length values were found in MT and in family B (Table 3). 


\section{Macrothink}

Table 3. Least square means for different morphometric traits measured in two families (A and B) of tambaqui (Colossoma macropomum) from the second generation of selective breeding evaluated in Santo Antônio de Leverger (MT) and Campo Grande (MS)

\begin{tabular}{|c|c|c|c|c|c|}
\hline \multirow[b]{2}{*}{ Location } & \multirow[b]{2}{*}{ Family } & \multicolumn{4}{|c|}{ Trait } \\
\hline & & Weight (g) & SL (cm) & BC (cm) & HL (cm) \\
\hline \multirow{2}{*}{ MT } & A & $1320.5 \pm 203.3 \mathrm{Ba}$ & $33.0 \pm 1.6 \mathrm{Ba}$ & $34.8 \pm 1.9 \mathrm{Aa} \stackrel{0}{\stackrel{9}{\epsilon}}$ & MT $12.3 \pm 2.5 \mathrm{a}$ \\
\hline & B & $1369.5 \pm 197.5 \mathrm{Aa}$ & $33.4 \pm 1.5 \mathrm{Ab}$ & $35.1 \pm 1.8 \mathrm{Aa} \stackrel{8}{\Xi}$ & MS $11.6 \pm 0.9 b$ \\
\hline \multirow{2}{*}{ MS } & A & $1131.6 \pm 153.8 \mathrm{Bb}$ & $32.7 \pm 1.6 \mathrm{Ba}$ & $33.6 \pm 1.4 \mathrm{Bb}$ 光 & $\mathrm{A} 11.7 \pm 2.6 \mathrm{~b}$ \\
\hline & B & $1417.6 \pm 220.7 \mathrm{Aa}$ & $34.8 \pm 1.7 \mathrm{Aa}$ & 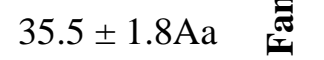 & B $12.2 \pm 2.3 \mathrm{a}$ \\
\hline $\begin{array}{l}\text { Location } \times \text { Fan } \\
(\text { P-value })\end{array}$ & & $<0.0001$ & $<0.0001$ & $<0.0005$ & 0.1372 \\
\hline
\end{tabular}

In the case of significant interactions, means followed by uppercase letters compare families in the same location and means followed by lowercase letters compare locations in the same family. Common letters indicate that the means do not differ statistically according to Tukey's test $(\mathrm{P}<0.05)$.

In the case of non-significant interactions, different lowercase letters indicate differences between locations regardless of family and between families regardless of location.

SL: standard length; BC: body circumference; HL: head length.

$(P$-value $)=$ obtained in the analysis of variance for the location $\times$ family interaction.

Considering that the breeding program is focused on selection for weight, family B stood out for this trait in comparison with family A in both farming locations. A genotype $\times$ environment interaction effect was observed, with a higher $(\mathrm{P}<0.05)$ weight found in family A reared in $\mathrm{MT}$, where as family B displayed no significant differences between the two locations (Table 3; Figure 7).

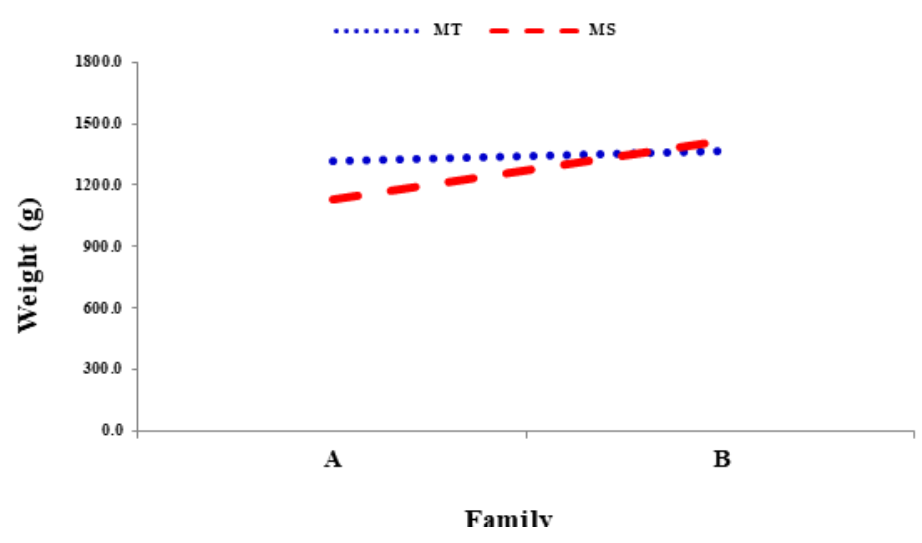

Figure 7. Genotype $\times$ environment (location $\times$ family) interaction effect on weight in two families (A and B) of tambaqui (Colossoma macropomum) from the second generation of selective breeding evaluated in Santo Antônio de Leverger (MT) and Campo Grande (MS) 


\section{Discussion}

In the MT tanks, water temperature fluctuated by $6.4 \%$ over the 431 experimental days. The lowest temperature was recorded in the winter $\left(24.6^{\circ} \mathrm{C}\right)$, which was near the range of 25.0 to $32.0^{\circ} \mathrm{C}$ characterized as adequate by Boyd (1998), for tropical fish (Figure 2). In the MS tanks, water temperature varied by $9.9^{\circ} \mathrm{C}$ during the same period, this is a larger variation than that observed in MT.

In the winter, the minimum observed temperature was $18.0^{\circ} \mathrm{C}$, which is $6.6 \%$ lower than the temperature recorded in MT in the same period and far from the temperature range considered ideal by Boyd (1998), for tropical fish. The maximum temperature recorded in MT $\left(31.0^{\circ} \mathrm{C}\right)$ was $3.1^{\circ} \mathrm{C}$ higher than in MS $\left(27.9^{\circ} \mathrm{C}\right)$. The lower water temperature observed in the tanks in MS might have affected the growth of the fish, as they were outside the thermal comfort zone (Silva et al., 2016).

The dissolved oxygen levels in the water were similar in both rearing environments, with values close to the ideal defined by Boyd (1998) for tropical fish $\left(5 \mathrm{mg} \mathrm{L}^{-1}\right)$. However, for a good part of the experiment (including the start and end), medium values were recorded in both locations. Such fluctuations observed in the two rearing environments are common in semi-intensive production systems, where the water renewal rate is lower than $10 \mathrm{~L} / \mathrm{s} / \mathrm{ha}$ due to the action of phytoplankton (Ribeiro et al., 2001).

Throughout the experimental period, the water $\mathrm{pH}$ in the two rearing environments remained within the range recommended by Boyd (1998) for tropical fish (between 6 and 9). Therefore, this water chemical property did not interfere with fish growth. The $\mathrm{pH}$ fluctuated more in the MT tanks (6.2 to 8.9) than in the MS tanks (7.9 to 8.9), although all values were within the threshold deemed adequate for tropical-fish farming.

Weight is the main variable under evaluation in the tambaqui breeding program. In this respect, in the present study, there were differences in performance between the families (A and B) evaluated in MS, where family B stood out with a $12.5 \%$ higher growth than family A. Based on the estimates obtained by fitting the Gompertz models for the prediction of growth curves, the highest weight values for both families were obtained in Santo Antônio de Leverger (MT), where the fish were $38.6 \%$ (family A) and $29.8 \%$ (family B) heavier than in Campo Grande (MS).

Age at the inflection point was lower for family B in both locations, indicating the earliness of this family in reaching the period of accelerated growth in comparison with family A. This earliness was also observed in the two families reared in MT compared with MS. These data corroborate the assumption that, in environments with higher temperatures (MT), the fish from both families will have a better weight development.

Although the asymptotic value and specific growth rate for standard length were similar between the two families, age at the inflection point in the two locations was lower for family B, indicating their earlier growth compared with family A. In the environment with higher temperatures (MT), both families exhibited higher asymptotic rates and relative growth rates and lower ages at the inflection point, demonstrating the effect of temperature on the growth 
curve for standard length, with greater growth achieved in the hotter environment.

Family B showed a higher asymptotic weight for head growth in both locations. Family A exhibited higher relative growth rates and age at the inflection point, which shows that despite having higher relative growth rates, this growth occurred later than in family B, which influenced its asymptotic weight. The growth of this morphometric trait (head size) is not desirable, since it directly affects the final yields of carcass and filet (Souza and Inhamuns, 2011; Maghelly et al., 2014; Vandeputte et al., 2017).Thus, this trait can be implemented in selective breeding programs, where producers should select animals with a shorter head length, since there are differences in all curve parameters between the families.

The analysis of growth curve parameters for body circumference in MT shows that only age at the inflection point differed, with the lower value obtained by family B. This result indicates an earlier period of accelerated growth in this family. The same was observed in MS; however, the asymptotic value was also different, with higher results found for family B. This trait may result in increased carcass yield, and, as such, it may be implemented in the selective breeding program.

The analysis performed when both families were at an equal weight (approximately $1300.0 \mathrm{~g}$ ) revealed the superior growth of family B for weight and morphometric traits in both locations (except for body circumference in MT), indicating that this family stood out in growth regardless of the environment (lower or higher temperature). For head length, better growth was seen in family B irrespective of the farming location, suggesting a lack of a genotype $\times$ environment interaction effect for this morphometric trait. The genotype $\times$ environment interaction analyses showed that weight and body circumference were superior in family $\mathrm{A}$ in MT, whereas the best results for standard length were obtained in family B reared in MS.

These results reinforce the idea that, depending on the temperature variation in the production environment (higher temperatures, for instance), better performance and growth may be observed in one family, or there may even be differences between distinct genetic groups. Thus, we stress the importance of using genetically selected individuals for production in environments with lower temperatures. In this scenario, it may be useful to select specific groups that with stand particularities of the growing environment, considering the existence of differences in growth and performance curves in a location with lower temperatures.

In distinct production environments, selectively bred animals may exhibit variations in performance (Strandberg et al., 2000; Ambrosini et al., 2012). Therefore, analyzing them in different environments (e.g., different temperatures) may allow the selection of one or more families that are more tolerant to a given rearing condition, in the breeding program (Espasandin et al., 2011; Silveira et al., 2014).

Many studies have shown considerable genetic gain from selective breeding in aquatic organisms, e.g., Nile tilapia (Ridha, 2006; Ponzoni et al., 2011; Thodesen et al., 2011), carp (Nguyen, 2016), rainbow trout, Atlantic salmon, and catfish (Mcandrew and Napier, 2011). Although fish breeding in Brazil is rather recent, the breeding of Nile tilapia - an exotic species is well-established in the country, with satisfactory genetic gains obtained in each 
generation of selection (Neto et al., 2012; Oliveira et al., 2012; Porto et al., 2015; Oliveira et al., 2016).

\section{Conclusion}

The current findings reveal considerable differences in growth between the families (A and B) in distinct rearing environments, with superior results achieved in regions with lower temperatures. These differences are mainly related to age at the inflection point, which makes it a decisive factor to demonstrate the earliness of tambaqui for weight gain.

\section{Acknowledgments}

This study was financed in part by the Coordenação de Aperfeiçoamento de Pessoal de Nível Superior - Brasil (CAPES) - Finance Code 001, Fundação Universidade Federal de Mato Grosso do Sul - UFMS/MEC - Brasil, Conselho Nacional de Desenvolvimento Científico e Tecnológico - CNPq(307486/2015-0), Fundação Universidade Federal de Mato Grosso UFMT/MEC - Brasil, Delicious Fish and Bom Futuro Fish Farms.

\section{References}

Ambrosini, D. P., Carneiro, P. L. S., Neto, J. B., Malhado, C. H. M., Filho, R. M., \& Cardoso, F. F. (2012). Interação genótipo $\times$ ambiente para peso ao ano em bovinos Nelore Mocho no Nordeste do Brasil. Pesquisa Agropecuária Brasileira, 47, 1489-1495. https://doi.org/10.1590/S0100-204X2012001000011

Araujo-Lima, C., \& Goulding, M. (1998). Os frutos do tambaqui. Ecologia, conservação e cultivo na Amazônia. Sociedade Civil Mamirauá/ CNPq/ Rainforest Alliance. Brasília, DF, pp 120-186.

Boyd, C. E. (1998). Water Quality for Pond Aquaculture. International Center Experiment Station. https://doi.org/10.1007/978-1-4615-5407-3

De Mello, F., Oliveira, C. A. L., Ribeiro, R. P., Resende, E. K., Povh, J. A., Fornari, D. C., ... Streit, D. (2015). Growth curve by Gompertz nonlinear regression model in female and males in tambaqui (Colossoma macropomum). Anais da Acadêmia Brasileira de Ciências, 87, 2309-2315. https://doi.org/10.1590/0001-3765201520140315

Espasandin, A. C., Urioste, J. I., Campos, L. T., \& Alencar, M. M. (2011). Interação genótipo $\times$ país para peso à desmama das populações angus do Brasil e Uruguai. Revista Brasileira de Zootecnia, 40, 568-574. https://doi.org/10.1590/S1516-35982011000300014

Fialho, F. B. (1999). Interpretação da curva de crescimento de Gompertz. Concórdia. Embrapa- CNPSA, p.1-4. Comunicado Técnico 237.

IBGE. (2020). Instituto Brasileiro de Geografia e Estatística - Pesquisa Pecuária Municipal. [Online] Available: http://www.sidra.ibge.gov.br/bda/tabela/listabl.asp?c=3940\&z=t\&o=21 (Mar 17, 2020).

Inoue, L. A. K. A., Boijink, C. L., Ribeiro, P. T., Silva, A. M. D., \& Affonso, E. G. (2011). Avaliação de respostas metabólicas do tambaqui exposto ao eugenol em banhos anestésicos. Acta Amazonica, 41, 327-332. https://doi.org/10.1590/S0044-59672011000200020 
Lopera-Barrero, N. M., Ribeiro, R. P., Povh, J. A., Vargas, L. D. M., Poveda-Parra, A. R., \& Digmayer, M. (2011). As principais espécies produzidas no Brasil. In N.M. Lopera-Barrero, R.P. Ribeiro, J.A. Povh, L. D. M. Vargas, A.R. Poveda-Parra \& M. Digmayer (Eds.), Produção de organismos aquáticos: uma visão geral no Brasil e no mundo. Guaiba: Agrolivros. pp 143-215.

Maghelly, O. R., Huergo, G. M., Zaniboni Filho, E., \& Enke, D. B. S. (2014). Características morfométricas e rendimento corporal do suruvi Steindachneridion scriptum agrupados por sexo. Boletim do Instituto de Pesca, 40, 419-430.

Marcos, R., Povh, J. A., Fornari, D. C., Oliveira, C. A. L., Ribeiro, R. P., Lopera-Barrero, N. M., ... Murari, P. J. F. (2016). Weight gain and morphometric growth of genetically improved tambaqui (Colossoma macropomum). Semina Agrárias, 37, 2521-2527. https://doi.org/10.5433/1679-0359.2016v37n4Sup11p2521

Mcandrew, B., \& Napier, J. (2011). Application of genetics and genomics to aquaculture development: Current and future directions. Journal of Agricultural Science, 149, 143-151. https://doi.org/10.1017/S0021859610001152

Neto, R. V. R., Freitas, R. T. F., Serafini, M. A., Costa, A. C., Freato, T. A., Rosa, P. V., \& Allaman, I. B. (2012). Interrelationships between morphometric variables and rounded fish body yields evaluated by path analysis. Revista Brasileira de Zootecnia, 41, 1576-1582. https://doi.org/10.1590/S1516-35982012000700004

Nguyen, N. H. (2016). Genetic improvement for important farmed aquaculture species with a reference to carp, tilapia and prawns in Asia: Achievements, lessons and challenges. Fish and Fisheries, 17, 483-506. https://doi.org/10.1111/faf.12122

Oliveira, C. A. L., Ribeiro, R. P., Streit Júnior, D., Povh, J. A., \& Resende, E. K. (2012). Melhoramento genético de peixes uma realidade para a piscicultura brasileira. Panorama da Aquicultura. pp 38-47.

Oliveira, C. A. L., Ribeiro, R. P., Yoshida, G. M., Kunita, N. M., Rizzato, G. S., Oliveira, S. N., \& Nguyen, N. H. (2016). Correlated changes in body shape after Five generations of selection to improve growth rate in a breeding program for Nile tilapia Oreochromis niloticusin Brazil. Journal of Applied Genetics, 57, 487-493. https://doi.org/10.1007/s13353-016-0338-5

Ponzoni, R. W., Hamzah, A., Tan, S., \& Kamaruzzaman, N. (2005). Genetic parameters and response to selection for live weight in the GIFT strain of Nile Tilapia (Oreochromis niloticus). Aquaculture, 247, 203-210. https://doi.org/10.1016/J.Aquaculture.2005.02.020

Ponzoni, R. W., Nguyen, N. H., Khaw, H. L., Hamzah, A., Bakar, K. R. A., \& Yee, H. Y. (2011). Genetic improvement of Nile tilapia (Oreochromis niloticus) with special reference to the work conducted by the World Fish Center with the GIFT strain. Aquaculture, 3, 27-41. https://doi.org/10.1111/j.1753-5131.2010.01041.x

Porto, E. P., Oliveira, C. A. L., Martins, E. N., Ribeiro, R. P., Conti, A. C. M., Kunita, N. M., ... Porto, P. P. (2015). Respostas à seleção de características de desempenho em tilápia do 
$\begin{array}{lllll}\text { Nilo. } & \text { Pesquisa } & \text { Agropecuária } & \text { Brasileira, } & 50,\end{array}$ https://doi.org/10.1590/S0100-204X2015000900002

Regazzi, A. J., \& Silva, C. H. O. (2004). Teste para verificar a igualdade de parâmetros e a identidade de modelos de regresão não-linear. I. Dados no delineamento inteiramente casualizado. Revista Matemática e Estatística, 22, 33-45.

Ribeiro, R. P. (2001). Construção de tanques. In H. L. M. Moreira, L. Vargas, R. P. Ribeiro \& S. Zimmermann (Eds.), Fundamentos da moderna aquicultura. Canoas: ULBRApp. 45-52.

Ridha, M. T. (2006). Comparative study of growth performance of three strains of Nile tilapia, Oreochromis niloticus, L. at two stocking densities. Aquaculture Research, 37, 172-179. https://doi.org/10.1111/j.1365-2109.2005.01415.x

Silva, T. S. C., Inoue, L. A. K. A., \& Fietz, C. R. (2016). Influência do clima, fenômenos e mudanças climáticas no manejo da piscicultura. Dourados: Embrapa Agropecuária Oeste, pp.28.

Silveira, M. V., Souza, J. C., Silva, L. O. C., Freitas, J. A., Gondo, A., \& Ferraz Filho, P. B. (2014). Interação genótipo $\mathrm{x}$ ambiente sobre características produtivas e reprodutivas de fêmeas Nelore. Archivos de Zootecnia, 63, 223-226. https://doi.org/10.4321/S0004-05922014000100026

Souza, A. F. L., \& Inhamuns, A. J. (2011). Análise de rendimento cárneo das principais espécies de peixes comercializadas no Estado do Amazonas, Brasil. Acta Amazônica, 41, 289-296. https://doi.org/10.1590/S0044-59672011000200015

Strandberg, E., Kolmodin, R., Madsen, P., Jensen, J., \& Jorjani, H. (2000). Genotype by environment interaction in Nordic dairy cattle studied by use of reaction norms. In: Interbull Meeting, Bled, Slovenia, 41-45. https://doi.org/10.1080/09064700252806380

Thodesen, J., Rye, M., Wang, Y. X., Yang, K. S., Bentsen, H. B., \& Gjedrem, T. (2011). Genetic improvement of tilapias in China: genetic parameters and selection responses in growth of Nile tilapia (Oreochromis niloticus) after six generations of multi-trait selection for growth and fillet yield. Aquaculture, 322, 51-64. https://doi.org/10.1016/j.aquaculture.2011.10.010

Vandeputte, M., Puledda, A., Tyran, A. S., Bestin, A., Coulombet, C., Bajek, A., ... Haffray, P. (2017). Investigation of morphological predictors of fillet and carcass yield in European sea bass (Dicentrarchus labrax) for application in selective breeding. Aquaculture, 470, 40-49. https://doi.org/10.1016/j.aquaculture.2016.12.014

\section{Copyright Disclaimer}

Copyright for this article is retained by the author(s), with first publication rights granted to the journal.

This is an open-access article distributed under the terms and conditions of the Creative Commons Attribution license (http://creativecommons.org/licenses/by/4.0/). 